\title{
Philosophical and research aspects of diversity
}

\section{[Diverzita vo filozofickom a vyskumnom ponati]}

\author{
Jana Duchovicova
}

DOI: 10.18355/XL.2018.11.01XL.05

\begin{abstract}
The study analyzes diversity in pedagogy, philosophical fundamentals influencing this reality more significantly in the twentieth century. It limits the equity in the educational reality as a challenge for reflection of the diversity in education and analyzes the diversity as a construct of studies carried out in pedagogy with an overview of the chosen conclusions. It focuses on the aspects of pedagogical diversities of pupils' population, mainly in the language, culture and ethnical heterogeneity as well as heterogeneity in the level of cognitive presumptions, mental abilities, and personal qualities, diagnostics of the pupils' diversity as the source for selecting appropriate pedagogical measurements.
\end{abstract}

Key words: diversity, equity, inclusion, differentiation, heterogeneity in educational environment, diversity in teacher's point of view, diversity in tertiary education

\begin{abstract}
Abstrakt
Štúdia analyzuje ponímanie diverzity v pedagogike, filozofické fundamenty, ktoré mali na toto poňatie $\mathrm{v}$ dvadsiatom storočí výraznejší vplyv, vymedzuje ekvitu v edukačnej realite ako výzvu pre reflexiu diverzity v edukácii a analyzuje diverzitu ako konštrukt výskumu v pedagogike s prehl'adom vybraných záverov realizovaných výskumov. Zameriava sa na aspekty pedagogickej diverzity žiackej populácie, najmä $\mathrm{v}$ rovine jazykovej, kultúrnej a etnickej heterogenity a heterogenity v rovine kognitívnych predpokladov, mentálnych schopností a osobnostných vlastností a diagnostiky žiackej diverzity so zretel'om na otázky dotýkajúce sa rôznorodosti žiakov ako zdroja výberu pedagogických opatrení.

Kl'účové slová: diverzita, filozofia diverzity, ekvita, inklúzia, diferenciácia, heterogenita $\mathrm{v}$ edukačnom prostredí, ponímanie diverzity učitel'mi, diagnostické kompetencie učitel'ov, diverzita v terciárnom vzdelávaní
\end{abstract}

\section{Úvod}

Rozmanitost' - diverzita - je aktuálne skúmaná v mnohých vedných oblastiach. Diverzita predstavuje celosvetový fenoménom dotýkajúcim sa všetkých oblastí kultúrneho života včítane vzdelávania. Predstavuje zdroj poznania heterogenity a determinantov rôznych javov a vo vzdelávaní je považovaná za zdroj nových príležitostí a inovácií orientovaných na dosahovanie efektívnejších výsledkov edukácie, či už v dimenzii osobných, individuálnych efektov alebo $\mathrm{v}$ dimenzii spoločenskej prosperity. V európskom priestore sú vyvíjané mnohé iniciatívy, ktoré sa snažia o podporu rozmanitosti a rozvoj diverzifikovanej školskej populácie, prostredníctvom vytvárania a ponuky kvalitných edukačných programov, implementujúcich princípy inklúzie, ekvity, rešpektu, vzájomnosti a humanity. Súčast'ou projektovania optimalizovaných edukačných postupov je výskum diverzifikovanej školskej populácie a rozmanitosti edukačných potrieb, ktoré z nej plynú, s ciel'om podporit kvalitu výchovy a vzdelávania.

XLinguae, Volume 11 Issue 1XL, January 2018, ISSN 1337-8384, eISSN 2453-711X 


\section{Pedagogické a filozofické ponímanie diverzity}

Vytváranie rovnosti šancí v prístupe k vzdelaniu môže zásadným spôsobom ovplyvnit' kvalitu sociálnej inklúzie, a tým kvalitu života jednotlivcov v spoločnosti. Diverzita v školských podmienkach predstavuje pochopenie a poznanie prepojenosti l'udskej kultúry a prírodného environmentu, neustále vyjadrovanie vzájomného rešpektu, učitel'ovu toleranciu, uvedomenie si toho, že osobná, kultúrna a inštitucionálna diskriminácia vytvára pretrvávajúce privilégiá len pre niektorých a neustále vytvára znevýhodnenia pre iných.

Snahy o rešpektovanie akýchkol'vek individuálnych potrieb vyplývajúcich z diverzity žiackej populácie (jej antropogénneho, psychogénneho a sociokultúrneho kontextu) majú v sebe základ afirmatívnej akcie, mali by však dostat' možnost' byt' vnímané ako zdroj vzájomného obohacovania.

NEA (National Education Association) definuje diverzitu ako spôsob, ktorým možno vysvetlit' identickost' a jedinečnost' jednotlivcov súčasne. Rozmanitost' vyplýva zo špecifík rasy, etnického pôvodu, jazyka, kultúry, náboženstva, pohlavia, sexuálnej orientácie, psychických a fyzických schopností, socio-ekonomického statusu, imigračných okolností a pod.

Rozmanitost' (diverzita) sama o sebe nepredstavuje pojem hodnoty, ale vyjadruje spôsob, akým l'udia reagujú na rôznorodost', pričom tento spôsob je determinovaný hodnotovou orientáciou, postojmi a presvedčením. Akceptácia rozmanitosti predstavuje hlavný princíp sociálnej spravodlivosti - ekvity - rovnakého prístupu ku všetkým žiakom. Výsledky vzdelávania v tomto kontexte závisia len od vynaloženého úsilia žiaka a nie od okolností, ktoré žiak/študent nemôže zmenit'. Podstatou ekvity je rozvoj žiakov nad stanovené minimum s ciel'om dosiahnut' maximum vyplývajúce $z$ potenciálu jednotlivca.

Ak vychádzame $\mathrm{z}$ definovania predmetu skúmania pedagogiky diverzita predstavuje jav determinujúci edukačné procesy $\mathrm{v}$ danom prostredí, ale tiež ovplyvňujúci efekty edukácie v zmysle osobnostných zmien i v zmysle spoločenských zmien odrážajúcich sa na jednej strane vo vzdelanostnej štruktúre populácie a vzdelanostnom potenciáli spoločnosti a na strane druhej v ekonomickej efektivite vynaložených financií na oblast' vzdelávania.

Charakteristika diverzity v edukácii je mnohospektrálna. Pri skúmaní jej podstaty je potrebné zaoberat' sa aspektmi metafyziky a ontológie, noetickej analýzy, pretože môžu tvorit' jadro poznania diverzity. Nemenej významná je etická a axiologická analýza diverzity objasňujúca jej hodnotovú povahu, ako aj analýza diverzity z aspektu politickej filozofie, pretože sekularizáciou spoločností sa väčšina atribútov svetonázorovej diverzity presunula do sféry politiky.

G. Pintes (2013) konštatuje, že príčina intenzívnejšieho záujmu pedagogiky o rozmanitost' $\mathrm{v}$ edukačných podmienkach tkvie aj v inovovaných a aktualizovaných generálnych zámeroch edukácie, vyplývajúcich zo zmenených celospoločenských, globálnych a bytostných ciel'ov našej existencie. Ako autor konštatuje, prvotnou otázku k pochopeniu tohto záujmu má byt' to, čo sa edukáciou snažíme dosiahnut', aký je súčasný obraz človeka, označovaného za vzdelaného, vychovaného a schopného nielen spoločenskej, ale aj individuálnej existencie. „Napriek tomu, že diverzitu chápeme ako prirodzený jav, k realizácii väčšiny tvorivých procesov potrebujeme vytvorit' takú základňu, v ktorej sú typické práve spoločné (homogénne, uniformné) znaky. Je to pravdepodobne prvý paradox, ktorý si väčšinou ani neuvedomujeme, lebo ho považujeme za celkom prirodzený. V praxi to znamená, že napriek skutočnej a úprimnej snahe a vôli rešpektovat' a podporit' diverzitu $v$ čo najširšej možnej miere, pre chod a fungovanie rôznych systémov ju potrebujeme limitovat, až potlačit'. Systém normativov, smernic, legislativy bol, je a bude vytváraný za tým účelom, aby vymedzoval a riadil procesy, pri ktorých budú pravidlá „hier“ rovnaké pre všetkých (alebo aspoň pre väčsinu). Skúmaním diverzity sa preto 
dostávame do situácie, kedy si potrebujeme objasnit', či je pre nás zaujímavá ako východiskový stav, alebo ako ciel', ktorý chceme podporit', resp. dosiahnut?"

V edukačnej realite v nadväznosti na uvedené paradoxne vyznievajú snahy orientované na prísne vymedzovanie vzdelávacích štandardov a testovanie ich zvládnutia $\mathrm{v}$ rôznych celoplošných monitoringoch, či iných kontrolných testoch, ak je v národných dokumentoch určujúcich politiku vzdelávania (napríklad Učiace sa Slovensko, 2017: 18) hlásaná a vyzdvihovaná požiadavka inklúzie, definovaná ako vzdelávanie žiakov s rôznorodým potenciálom, založená na individualizácii vyučovania. Následne sa objavujú otázky pedagógov, či je vôbec možné diferencovat' žiakov podl'a ich edukačných potrieb? Mnohým učitel'om, ktorí poznajú svojich žiakov, ich možnosti a predpoklady, leží na srdci adekvátnost' a primeranost' vlastného vyučovacieho pôsobenia, no neraz vd'aka štandardom majú pocit zviazaných rúk. Relatívne novým fenoménom sa v zahraničných školských systémoch stáva vypracovávanie vzdelávacích štandardov založených na rozmanitosti edukačného terénu, vyplývajúceho $\mathrm{z}$ výraznej akademickej odlišnosti žiakov v školských triedach. Ich podstatou je pedagogická práca založená na vysokej kvalite vyučovacích stratégií a požiadaviek. Inými slovami ak učitel' porozumie ako sú štandardy vypracovávané, ako sú v nich požiadavky na úroveň vedomostí, zručností, spôsobilostí a návykov zarad'ované, v konfrontácii s vyučovacou praxou, stojí na hranici možného rešpektovania diverzity a tvorby inkluzívneho edukačného prostredia. Konflikt medzi sústredením sa na vzdelávacie štandardy a orientáciou na jednotlivé potreby žiakov nastáva len vtedy, ak sú štandardy používané spôsobom, ktorý núti učitel'a ignorovat' poznatky o efektívnom vyučovaní a učení sa.

Hoci pojem diverzita je v našej proveniencii pojmom skôr novým, než tradičným, neznamená to, že by otázky individuality, špecifických potrieb a odlišností boli v pedagogickom, špeciálnopedagogickom, či psychodidaktickom výskume opomínané. Známejším a tradičnejším je pojem diferenciácia. V pedagogickej literatúre sa pojem objavuje v období postmoderny, približne v 60 -tych rokov, kedy sa začali výraznejšie uplatňovat' mnohé pozitívne reformné impulzy predovšetkým z dôvodu výrazných diferencií v dosahovaní úspechov školských systémov jednotlivých krajín na medzinárodnej úrovni a škola musela čelit' ostrej kritike. Kritizoval sa najmä vnútorný život školy, pričom kritika bola taká rozsiahla a významná, že môžeme hovorit' o svetovej vzdelávacej kríze.

Postmoderna spochybnila väčšinu východiskových filozofických téz moderny, o ktorých sa myslelo, že predstavujú konštantnú a neprekonatel'nú paradigmu nášho sveta a sú natol'ko nespochybnitel'ným pilierom, že sa človek o ne môže s istotou opriet' v každej oblasti svojho života. Základný pilier moderny, vymedzenie človeka na základe racia, ktoré mu zodpovie väčšinu životných otázok, bolo spochybnené, $\mathrm{k}$ čomu $\mathrm{v}$ nemalej miere prispelo psychoanalytické hnutie reprezentované Freudom. V postmodernej filozofii, konštatuje G. Pintes (2013: 13), by sme však len t'ažko mohli nájst' taký koncept, ktorý bol jednoznačným fundamentom edukačnej diverzity. Korene treba hl'adat' v skorších obdobiach a v diskurzoch, ktoré tvoria len parciálnu oblast' globálne chápanej diverzity.

K základným fundamentom autor zarad’uje:

- Noetický fundament . Je postavený na liberalizme a dodnes predstavuje významné miesto $\mathrm{v}$ pozitivistických názoroch. „Podl'a liberálneho učenia je spoločnost' stavaná $z$ racionálnej spolupráce medzi sebou súperiacich jednotlivcov. Spoločnost' preto neposkytuje žiadnu oporu (právnu, morálnu) tým, ktorí v tomto súpereni ostanú porazení. Výnimkou sú len prípady, kedy sa úspech dosiahne prostriedkami, ktoré sú v rozpore so všeobecným záujmom (podvodom, násilím a pod.). Konštatuje, že neexistuje taká spoločnost', v ktorej by všetci

XLinguae, Volume 11 Issue 1XL, January 2018, ISSN 1337-8384, eISSN 2453-711X 
jednotlivci mohli súperit' za rovnakých podmienok, ked'že diverzita spoločnosti (a $v$ nej aj jednotlivcov) je natol'ko značná a typická, že spoločnost' musí tieto „,inakosti" vyrovnat' - kompenzovat' najmä legislativnym systémom. Vládnuce zoskupenie (politické, hospodárske, informačné) však v každej dobe dokázalo aj týmito prostriedkami manipulovat' spoločnost', a to často vidinou vytvorenia rovnakých podmienok pre každého. "V tomto diskurze je otázna najmä úprimnost' (morálny aspekt) toho, či praktickým presadením týchto ideálov sa v praxi môže naozaj uplatnit' akceptácia rôznorodosti.

- Morálno - axiologický fundament. Vychádza z kritiky liberalizmu a neoliberalizmu. Neomarxisti na rozdiel od marxistov verili v to, že aj cesta evolúcie môže priviest' l'udstvo k emancipácii a tým aj k všeobecnému rešpektovaniu a akceptácii odlišností. „Cielom zmeny podl’a H. Marcuseho je taká spoločnost', v ktorej sú garantované slobodné možnosti človeka pre jeho prirodzený vývin. Tieto myšlienky sa stali akýmsi programom moderného anarchizmu v 60. rokoch 20. storočia. Pre všeobecné uplatnenie edukačnej diverzity sa však takýto spôsob nejavi ako optimálny. " Tým, že človek v neomarxistickom diskurze prichádza k uvedomeniu si možností alternatívneho osudu, rozhoduje sa konat'. História však ukázala, že ku konaniu sa odhodlali len niektoré skupiny spoločnosti (študentstvo a nižšia sociálna vrstva), ktoré nemali čo stratit' a namiesto progresu často prišiel ešte ovel'a výraznejší regres spoločnosti, aký by sa dal očakávat', konštatuje G. Pintes..

- Metodicko - pedagogický fundament. Znamená teoreticko - koncepčné východisko edukačnej diverzity, na základe ktorého môžeme uplatnit' čo najširšie spektrum prejavov rôznorodosti v edukačnom procese. Spadá sem filozofia existencializmu, ktorá sa odrazila najmä $\mathrm{v}$ reformno-pedagogických hnutiach. Metódy reformnej pedagogiky založené na vyzdvihovaní osobného zážitku, sebarozvoji, sebarealizácii a sebaaktualizácii vyzdvihli v pedagogickom prostredí subjektivizmus a do popredia sa dostal vol'ný - slobodný model výchovy z hladiska riadenia výchovno-vzdelávacieho procesu.

Ako sme už naznačili, štúdium jedinečnosti, a teda aj žiackej odlišnosti nie je novou záležitost'ou a hoci sa dlhodobo hl'adajú a formulujú príčiny neúspechu a problémov vo výchove a vzdelávaní, nemôžeme tvrdit', že by pedagogická teória zaujala k týmto otázkam jednoznačný postoj. Uvedomujeme si, že vzhl'adom k rozmanitosti, mnohofaktorovosti a širokospektrálnosti problémov súvisiacich s výchovou, ako aj diverzitu žiakov je to úloha vel'mi náročná a je logické, že doteraz nebol vytvorený jednotný model, systém, ktorým by sa diferenciácia a inklúzia mala riadit'. To je zároveň príčina, prečo nachádzame $\mathrm{v}$ didaktikách a metodikách odporúčania individuálnych postupov so žiakmi konkrétnych kvalít skôr ojedinele.

Diferencie, ktoré boli objektom výskumu pramenili z diverzity úrovne kognitívnych funkcií, učebných štýlov, schopností, tvorivosti a záujmov, pričom pedagogika v menšej miere skúmala príčiny diverzity a výraznejšie sa zameriavala na jej dopad v procese výchovy a vzdelávania (vplyv na prospech, výkon, správanie, komunikáciu, kooperáciu, motiváciu, sebahodnotenie, sebareguláciu, hodnoty a pod.) a hl'adanie optimálnych stratégií pre procesy výchovy a vzdelávania (diferenciáciu ciel’ov, diferenciáciu, metód, diferenciáciu foriem, prostriedkov) s dôrazom na rešpektovanie žiackej individuality.

Pojem, s ktorým pracovala pedagogická veda $\mathrm{v}$ našich podmienkach častejšie je heterogenita edukantov, chápaná ako odlišnost', inakost', pričom si dovolíme konštatovat', že uplatnenie princípov vnútornej diferenciácie sledovalo ciel' primárnej prevencie v kontexte disocializácie a exklúzie skôr v širšom sociálnom zmysle než v zmysle priamej pedagogickej intervencie. Pojem heterogenita sa opieral o koncept vzdelávacích potrieb, v užšom zmysle slova, teda o koncept špeciálnych edukačných potrieb (legislatíva pracuje s pojmom špeciálne výchovno-vzdelávacie 
potreby), čím bol výskum prioritne orientovaný na problémy podpory a vzdelávania žiakov s rôznou úrovňou schopností a prospechu (podpriemerní, priemerní žiaci, žiaci nadaní, prospievajúci, neprospievajúci), žiakov s postihnutím (mentálnym, zmyslovým, telesným, viacnásobným a pod.), s narušením (narušenou komunikačnou schopnost'ou, psychosociálne a emocionálne narušených a pod.) a poruchami (učenia a správania). V posledných desat'ročiach sa výskumné uchopovanie heterogenity žiakov výrazne rozšírilo, a to najmä o témy kultúrnej a etnickej heterogenity (v našich podmienkach sú to predovšetkým špecifiká vzdelávania žiakov rómskeho etnika), ale tiež jazykovej heterogenity (špecifiká vzdelávania bilingválnych žiakov, žiakov s odlišným materinským jazykom a pod.) a v neposlednom rade o otázky pohlavnej heterogenity. Výskumami v oblasti kognitívnej psychológie sa postupne rozšírilo pole záujmu pedagogiky o témy heterogenity $\mathrm{v}$ učení a jeho štýloch, úrovni kognitívnych funkcií, koncepcií, prekoncepcií a miskoncepcií žiakov a heterogenity osobnostných charakteristík (temperament, tvorivost', motivácia, postoje, sebapoňatie, integrovanost' a ich vzt’ah k školskému výkonu pod.). (bližšie Duchovicova, 2012, 2013).

Bližšie sa analýzou heterogenity zaoberajú autorky V. Hajkova, I. Strnadova (2010) a v zmysle vymedzenia jednotlivých typov je aj v našich podmienkach možné uvažovat' o rôznorodosti (diverzite) žiackej a študentskej populácie.

1. Kultúrna a etnická heterogenita - etnická, jazyková a kultúrna odlišnost' by mala byt' v škole vnímaná bez akéhokol'vek náznaku posudzovania v zmysle cudzosti a odsudzovania. Pedagogickými otázkami národnosti, etnickou a kultúrnou diverzitou v spoločnosti sa zaoberá interkultúrna pedagogika.

2. Jazyková heterogenita - táto otázka je na Slovensku vnímaná mimoriadne citlivo najmä vo vzt’ahu k národnostným menšinám, ale vynára sa aj $\mathrm{v}$ súvislosti so vzdelávaním žiakov rómskeho etnika a narastajúcim počtom vzdelávajúcich sa detí cudzincov (migrantov) v našej krajine.

3. Heterogenita pohlavia a genderové aspekty inklúzie - sú riešené ako problémy dvoch typických subkultúr, pričom neustále dochádza k snahám o odhalenie dynamiky vzt’ahov v ich koedukácii, na základe vzájomnej odlišnosti.

4. Veková heterogenita-vzt'ahy medzi žiakmi rôznych vekových skupín a kategórií, rovnako ako medzi vrstovníkmi, hrajú významnú úlohu pri ul'ahčovaní osobnostného, spoločenského a morálneho rozvoja jednotlivcov, preto sú taktiež predmetom rozsiahlych výskumov.

5. Heterogenita kognitivnych predpokladov a mentálnych schopností Jedným z najznámejších odporcov selekcie žiakov na základe kognitívnych schopností je R. Feuersein a kol. (1980), ktorý je autorom jedného z najrozšírenejších stimulačných programov. R. Feuerstein si všimol, že vel'a detí, ktoré zlyhávali v školskom prostredí $\mathrm{v}$ dôsledku toho, že nie sú schopné vyrovnat' sa $\mathrm{s}$ formálnymi nárokmi učenia, zároveň však boli úspešné v mimoškolskom prostredí, v hre i v poznávacej činnosti.

6. Rozdielnost' žiakov podl'a temperamentových charakteristík - temperamentom označujeme tú čast' osobnosti človeka, ktorá je určená prevažne biologicky a prejavuje sa predovšetkým spôsobom citového reagovania. K hlavným temperamentovým charakteristikám je možné zaradit' aktivitu, vzrušivost' a vytrvalost', na základe ktorých je možné pochopit' a predvídat' správanie žiakov a vyhnút' sa tak problémovým situáciám.

Viaceré teórie skúmajúce multikulturalitu a multikultúrnu teóriu sa pokúšajú o vymedzenie teoretického rámca diverzity. R. G. Tharp (1994) uskutočnil analýzu multikulturality postavenej na komplexnom rámci štyroch úrovní kauzálnych vývojových procesov, ktoré sú vo vzájomnej relácii, a tak ovplyvňujú l'udské správanie každého druhu. Zahrnul sem fylogenézu, etnogenézu, ontogenézu a mikrogenézu. Fylogenetická úroveň vysvetl'uje evolučný kontext vývojovej línie

XLinguae, Volume 11 Issue 1XL, January 2018, ISSN 1337-8384, eISSN 2453-711X 
druhov, teda i rás, etnogenéza vysvetl'uje kauzalitu procesov, ktoré ovplyvňovali podmienky existencie jednotlivých kultúr a národov a etnických skupín, ontogenéza sa orientuje na individuálny vývoj organizmu od počatia až po smrt' a mikrogenetická úroveň vysvetl'uje príčinné súvislosti rozmanitosti na základe akvizičných procesov ako je učenie, imitácia a pod. Opierajúc sa o uvedené je diverzita a multikulturalita problémom podstatne presahujúcim chápanie rozmanitosti len podla príslušnosti k určitej špecifickej skupine, pretože ide o široký komplex súvislostí podtrhujúcich individuálnu odlišnost'.

Opodstatnene tak veda včleňuje do svojho pojmového aparátu pojem pedagogickej diverzity, ktorý vobsahovom vymedzení je možné chápat' ako heterogenitu žiackej/študentskej populácie.

V súčasnosti sa pedagogika snaží o modernizáciu obsahu, metód, foriem vyučovania s ciel’om zvýšenia účinnosti a úrovne pedagogickej činnosti a aplikácia diferencovaného prístupu k žiakom podl'a ich záujmov a nadania je jej neoddelitel'nou súčast'ou. Prispieva k tomu aj prijatie filozofie ekvity v edukačnom prostredí. Ekvita znamená férový prístup, čo v praxi znamená, že na to, aby jedinec dosiahol výsledky adekvátne jeho schopnostiam, sú mu (mali by mu byt') poskytnuté prostriedky, ktoré berú do úvahy jeho konkrétnu východiskovú situáciu (sociálnu, fyzickú, psychickú, spoločenskú, intelektuálnu,...). Férový prístup stavia na princípoch ako spravodlivost', objektívnost'; berie do úvahy, že nie všetci sú na rovnakej úrovni, alebo v rovnakej situácii a preto by mali mat' poskytnuté to, čo najlepšie zodpovedá ich potrebám; očakávané sú výsledky zodpovedajúce jeho individuálnym schopnostiam a špecifickej situácii; s každým sa zaobchádza rovnocenne, pričom sa kladie dôraz na kvalitu. (Equity, 2014).

Mnohé oblasti žiackej diverzity však nie sú z pohl'adu pedagogickej vedy rozpracované komplexne. Vel'ké možnosti vidíme vodporúčaniach a hlavných ciel’och koncepcie rozvoja výchovy a vzdelávania, a to v kurikulárnej transformácii a v diverzifikácii metód a foriem vzdelávania a výchovy, zameraných na zážitkovú, motivačnú, autoregulujúcu, kreativizačnú, socializačnú a kognitivizačnú funkciu. Moderná škola $\mathrm{v}$ demokratických systémoch sa postupne odkláňa od selektívnej kategorizácie žiakov, sankcionovania ich neúspechov a striktného predpisovania rozsahu vedomostí, zručností a času, v priebehu ktorého si ich žiaci majú osvojit'. Hladá cesty, ako intenzívne pomôct' žiakom, aby proces ich učenia bol čo najúčinnejší. Ide o odklon od receptívnej, verbálnej a pamätovo založenej orientácie, znižujúcej možnosti individualizácie a smerovanie k rozvoju žiakov pomocou individualizácie a diferenciácie.

K východiskám pre tvorbu vzdelávacích stratégií dnešnej školy patria výsledky výskumov a tézy jednotlivých filozoficko-pedagogických koncepcií, napr.:

- proces učenia je ovplyvnený doterajšími skúsenost'ami a poznatkami žiaka a učitel' musí preto vediet', aké poznatky žiak má, aké sú modely jeho učenia, aké má spôsoby spracovávania informácií, aký je jeho štýl učenia;

- ak má vyučovanie rozvíjat' kritické myslenie a kognitívne funkcie žiaka, musí reflektovat' princípy sprostredkujúceho vyučovania vzt'ahujúce sa k motivácii, rozvíjaniu metakognitívnych procesov, inteligencie a učebnej kapacity a smerovat' k štrukturálnej modifikácii poznania a poznávania;

- je potrebné hl'adat' vhodné modely správania, ktoré sú v procese vyučovania postupne predstavované žiakom;

- je nevyhnutné spevňovat' správanie žiakov pozitívnou spätnou väzbou a je dôležitá praktická aplikácia všetkého vysvetleného;

- zdrojom vývoja osobnosti sú interakcie medzi osobami; 
- snažit' sa navodit' vo vyučovaní konflikt v poznaní, pretože sa ním zvyšuje pravdepodobnost' zaujatia poznávacieho postoja žiakom, v dôsledku nutnosti sociálnej regulácie;

- čím viac jedinec participuje na riešení učebných problémov, tým je efekt učenia vyšší, preto je potrebné využívat' čo najviac autentické učenie;

- používanie kooperatívneho vyučovania vedie k rozvoju individuálnej zodpovednosti, schopnosti plánovania, sociálnych zručností,

- uplatňovat' pravidlá neurodidaktického a psychodidaktického poňatia vyučovania.

Uvádzané vybrané stratégie a princípy podporujú potrebu prispôsobovat' edukačný proces individuálnym predpokladom a potrebám žiaka vyplývajúcim z ich diverzity - rozmanitosti. Koncept rozmanitosti musí zahrnút' prijatie a rešpekt. Diverzita je teda chápaná ako prijatie skutočnosti, že každý jednotlivec je jedinečný a uznanie príčin individuálnych rozdielov. Skúmanie rozdielov zároveň smeruje k chápaniu, rešpektu a ochrane celého environmentu. Koncept diverzity sa tak stáva priestorom pre pochopenie seba samého prostredníctvom tolerancie a poznávania rozmanitosti obsiahnutej osobnost'ou každého jednotlivca.

\section{Diverzita ako konštrukt výskumu orientovaného na pedagogickú inklúziu}

Súčast'ou projektovania optimalizovaných edukačných postupov v inkluzívnej škole je výskum diverzifikovanej školskej populácie a rozmanitosti edukačných potrieb, ktoré $\mathrm{z}$ nej plynú, s ciel'om podporit' kvalitu výchovy a vzdelávania. V odborných a vedeckých diskurzoch zahraničnej proveniencie je diverzita riešená dlhodobejšie (Baughn, 1999; . England, 1992; Jaap, 1999; Wittmer, 1992 a iní), sú zriad’ované centrá na výskum diverzity (napr. Center for Research on Education, Diversity \& Education).

Výskum sa orientuje aj na filozofický rozmer diverzity, transformujúci sa v teórii, ako aj konkrétny didaktický rámec jej rešpektovania v priamych výchovných a vzdelávacích intervenciách $\mathrm{s}$ dopadom na efektivitu vyučovania $\mathrm{v}$ poznatkovej oblasti, v oblasti personalizácie, tvorby vlastnej identity, sebapoňatia, sebahodnotenia, socializácie človeka a pod. v inkluzívnom prostredí.

Podstatne hlbší prienik do problematiky zaznamenávame v USA, ale aj v Austrálii, kde sa diverzita rieši ako základný problém plynúci z obrovskej rozmanitosti society, už niekol'ko desat'ročí. Edukačná politika diverzity sa výraznejšie orientuje na projektovanie adekvátneho kurikula a výber optimálnych vyučovacích stratégií vyplývajúcich $\mathrm{z}$ dokonalého poznania vzdelávaných skupín a ich edukačných potrieb (bližšie napr. Teele, 2007/2008; Rifkin, 2007/2008; Bernhardt, 2007/2008).

Európsky pohl'ad na problematiku diverzity je možné považovat' za „opatrnejší“, čo je pravdepodobne odozva aj na postmodernú filozofiu J. F. Lyotarda, M. Foucaulta, J. Derridu a i. (bližšie Caroll, 1987; Youdell, 2006 a i.).

V centre výskumnej pozornosti stojí sociokultúrna odlišnost', multikulturalita, jazyková (Haley, Hancock, et all. 2007/2008) genderová odlišnost', inakosti v kontexte špeciálnych výchovno-vzdelávacích potrieb, odlišnej sexuálnej orientácie (Bedford, 2009). Špecifický problém tvorí diverzita a jej výskum v postsekundárnom vzdelávaní (Higbee, Lundell, Duranczyk, ed., 2007). Spomenieme práce zamerané na vnímanie diverzity vo vysokoškolskom prostredí študentmi (Ghere , Kampsen, Duranczyk, Christensen, 2007), integráciu a inklúziu vo vysokoškolskom prostredí a jej multikultúrne, psychologické, či špeciálnopedagogické pozadie (Higbee , Siaka, Bruch, 2007; Christensen, 2007; Nieto, 2006), odlišnosti v správaní a motivácii vysokoškolákov a ich vplyve na učebné výsledky (Aragon, Kose, 2007). Výskumne sú tiež riešené otázky diverzity na druhom póle edukačného procesu v pedagogickom zbore (Stanley, 2006) a širšieho vnímania problémov učenia 
vyplývajúcich z diverzity a jej kultúrno - ekologického rámca (Murry, 2006; Verma, 2006).

$\mathrm{K}$ dispozícii je tiež stále viac dôkazov o tom, že iniciatíva $\mathrm{v}$ podpore diverzity a inklúzie má vplyv na zvýšenie počtu znevýhodnených študentov vo vysokoškolskom prostredí (Hurtado, Milem, Clayton, Pedersen, Allen, 1998; Smith, Schönfeld, 2000, Duchovicova, Rybansky, 2013b), no zatial' nie je možné hovorit' o dosiahnutí ekvity.

V našej proveniencii sme riešili výskumný problém orientovaný na poňatie diverzity $\mathrm{v}$ školskom prostredí, vychádzajúce $\mathrm{z}$ prijatia diverzity, ktorého ukazovatel'mi sú: budovanie inkluzívnej kultúry, tvorba inkluzívnej politiky a rozvíjanie inkluzívnej praxe (Booth, Ainscov, 2007) a $\mathrm{z}$ úrovne profesijnej kompetentnosti pedagógov vo vzt'ahu k napíňaniu týchto ukazovatel'ov, čím sme detekovali pripravenost' škôl napíňat' individuálne edukačné potreby detí, žiakov a študentov a jej limity v školskom prostredí (Duchovicova, Petrova, 2015).

$\mathrm{Z}$ výsledkov výskumu, orientovaného na zistenie prijatia diverzity $v$ školskom prostredi $\mathrm{v}$ jednotlivých indikátoroch inkluzivity vyplynulo, že prijatie diverzity $\mathrm{v}$ školskom prostredí sa celkovo pohybuje v rozmedzí mierne uplatňovaných až uspokojujúco uplatňovaných princípov inklúzie, pričom pozitívnejšie hodnotia budovanie inkluzívnej kultúry, uplatnenie inkluzívnych hodnôt a inkluzívnu prax (učitelia s praxou menej ako 5 a viac ako 15 rokov praxe. U učitel'ov expertov, s dížkou pedagogickej praxe viac ako 5 a menej ako 15 rokov, sme zaznamenali nižšie hodnotenia $\mathrm{v}$ prijímaní diverzity $\mathrm{v}$ školskom prostredí, avšak rovnako sa pohybujú v rozpätí mierne uplatňovaných princípov. Najnižšie priemery sme zaznamenali, a to u všetkých skupín učitel’ov, v indikátore mobilizácia zdrojov. Výsledok orientuje potrebu prípravy učitel'ov $\mathrm{k}$ realizácii sprostredkovaného učenia, vedeniu žiakov k vzájomnému zdiel’aniu svojich zručností, tradícií a skúseností, napr. z rôznych rodinných zázemí, kultúrnych odlišností. Je potrebné rozvíjanie komunikačných kompetencií a schopností učitel'ov pre sprostredkovávanie skúsenosti a zručnosti zdiel'at' s kolegami navzájom prostredníctvom metodických inštruktáží a hospitácií. Rozvíjat' schopnost' prípravy projektov pre získanie zdrojov na podporu inkluzívneho vzdelávania vo svojich triedach učitel'mi, rozvíjat' spôsobilosti učitel'ov v oblasti poznania zdrojov na podporu učenia žiakov/študentov a vytváranie vlastných zdrojov pre študentov intaktných, ako aj pre študentov s rôznym postihnutím a špecifickými potrebami.

Skúmanie učitel'ovho vnímania vlastnej profesijnej zdatnosti vo vzt’ahu $\mathrm{k}$ prijímaniu diverzity (uplatneniu jednotlivých indikátorov inklúzie) v školskom prostredí odhalilo, že učitelia hodnotia úroveň vlastných kompetencií v oblasti uplatnenia princípov inkluzívnej filozofie ako uspokojivú až miernu (učitelia vysokých škôl). Najvyššia miera hodnotenia vlastnej kompetentnosti prijatia diverzity a uplatnenia inkluzívnej filozofie je u učitel’ov prvého stupňa ZŠ. Zároveň nižšiu úroveň kompetencií, podl'a vlastného hodnotenia, majú učitelia II. stupňa ZŠ, SŠ a VŠ, výraznejšie v indikátoroch organizácia učenia, mobilizácia zdrojov a tvorba inkluzívneho prostredia a kultúry, preto by programy d’alšieho vzdelávania, zamerané na zvyšovanie úrovne kompetencií pedagogických zamestnancov sekundárneho vzdelávania, orientované na podporu inkluzívneho vzdelávania mali zahŕňat práve identifikované oblasti indikátorov. Pri analýze výsledkov sebareflexívneho posúdenia úrovne kompetencií v uplatňovaní princípov inklúzie a prijatia diverzity podl’a dížky pôsobenia sme zistili, že najnižšie hodnotia úroveň vlastných kompetencií učitelia $\mathrm{s}$ dížkou praxe 5 až 15 rokov, a to vo všetkých sledovaných indikátoroch.

Predmetom našich výskumov boli tiež aspekty pedagogickej diagnostiky v kontexte diverzity žiackej populácie so zretel’om na otázky dotýkajúce sa rôznorodosti žiakov ako zdroja výberu pedagogických opatrení (Duchovicova, 2013a). Podkladom expertízy bolo sebareflexívne posúdenie úrovne profesijnej kompetentnosti a indikátory diagnostiky: včasná depistáž, štruktúra diagnostického 
procesu a varieta školskej populácie a pedagogická diagnostika. Výskum preukázal, že úroveň pripravenosti učitel'ov na uskutočňovanie depistáže, orientovanej na adekvátne plánovanie vyučovania a výber pedagogických opatrení a intervencií v kontexte žiackej rôznorodosti v škole považujú učitelia za menej uspokojivú. Najmenej sú pripravení identifikovat' potreby vyplývajúce z gendrových odlišností, etnickej rozmanitosti a imigračných okolností, z čoho usudzujeme obsahové zameranie prípravy v oblasti pedagogickej diagnostiky. V štruktúre diagnostického procesu sú učitelia najmenej pripravení na stanovovanie pedagogickej diagnózy vychádzajúcej z genézy stavu žiaka, stanovenie diagnostickej hypotézy (predpokladu určujúceho postup diagnostikovania), vyslovenie prognózy a možností d'alšieho rozvoja žiaka. Úroveň vlastných kompetencií pre uskutočnenie depistáže na menej uspokojivej úrovni je identifikovaná vo vzt’ahu k etnickej rozmanitosti, fyzickým schopnostiam a zdravotnému stavu a imigračným okolnostiam. Za najnáročnejšie oblasti pedagogickej diagnostiky, vyplývajúce z rôznorodosti žiakov, považujú učitelia temperamentové, vôlové a iné osobnostné charakteristiky žiaka, rôznorodost' z hl'adiska ohrozenia poruchou správania alebo pozornosti, rôznorodost' $\mathrm{z}$ hl'adiska sociálnej pozície žiaka, či z hl'adiska ohrozenia špecifickou vývinovou poruchou.

$\mathrm{Z}$ uvedených zistení vyplýva potreba obsahového zamerania prípravy $\mathrm{v}$ oblasti pedagogickej diagnostiky.

Významným predpokladom pre rozvíjanie učitel'ských kompetencií je rozšírenie rozsahu pedagogickej praxe a konkretizácia oblastí praktickej prípravy zahŕňajúcej aspekty diverzity a variety žiakov v školskom prostredí, jej identifikácie a projektovania optimálnych pedagogických opatrení a didaktických intervencií opierajúcich sa o kvalifikovanú pedagogickú diagnostiku.

V rámci výskumu diverzity vo vysokoškolskom prostredí sme iniciovali výskum zameraný na identifikáciu hodnotenia úrovne podpory rozmanitosti (diverzity) $\mathrm{v}$ prostredí vysokých škôl a miery inkluzivity $\mathrm{z}$ pohl'adu študentov príslušných vysokých škôl (Vargová, M. 2015). Z výsledkov vyplynulo, že študenti hodnotia diverzitu v prostredí škôl vel'mi pozitívne a toto prostredie je do významnej miery inkluzívne. Snaha škôl v zmysle podpory diverzity je študentmi oceňovaná, pričom nápomocné sú aj interné predpisy viažuce sa na kvalitu vzdelávania v skúmaných školách. Z výsledkov vyplýva, že škola je otvorená naozaj pre všetkých, študenti sa cítia byt' prijímaní pedagógmi, tiež spoluštudentmi, ale aj samotnou

školou. Inklúzia študentov je v prostredí škôl verejne prezentovaná ako ich politika, uplatňujú

sa tu princípy inklúzie, rešpekt, tolerancia, akceptácia, a pod. Identifikované bolo tiež ponímanie inklúzie vo vysokoškolskom prostredí medzi zahraničnými študentmi a nezahraničnými študentmi. Obidve skupiny študentov vnímajú diverzitu a mieru inkluzivity pozitívne. Zahraniční študenti vnímajú mieru inkluzivity v prostredí slovenských vysokých škôl vel'mi podobne ako nezahraniční. Ked’že zahraniční študenti predstavujú heterogénnu skupinu odlišnej skúsenosti, prípadne odlišnej etnicity a kultúry a táto skupina vníma mieru inkluzivity pozitívne, znamená to, že škola im poskytuje rovnaké podmienky, ako na domácej pôde. Škola teda vo významnej miere uspokojuje diverzitné podmienky študentov odlišnej etnicity a kultúry. Študenti spomedzi všetkých ukazovatel'ov diverzity najpozitívnejšie hodnotili organizáciu učenia. Z toho vyplýva, že študentom vyhovuje proces vzdelávania, je prispôsobovaný individuálnym potrebám študentov. Zdôrazňujeme, že ciel’om inklúzie nie je znižovanie nárokov na študentov s diverzitnými potrebami, od každého študenta sa musí vyžadovat' rovnaké množstvo vedomostí na dosiahnutie určitého hodnotenia. Z hodnotenia študentov d'alej vyplynulo, že školy naozaj poskytujú možnosti aj priestory pre aktivity, ktoré vyplývajú z ich záujmov, ich priestory sú bezbariérové a sú vybavené potrebnými pomôckami, ktoré študentom so špeciálnymi vzdelávacími potrebami ul'ahčujú vzdelávací proces. Školy tiež poskytujú možnost' 
výmenných študijných pobytov v zahraničí všetkým študentom, bez ohl'adu na ich rôznorodost'. Študenti sa teda necítia žiadnym spôsobom znevýhodnení. Výskum d'alej preukázal, že významný rozdiel v ponímaní inklúzie existuje medzi študentmi doktorandského štúdia $\mathrm{v}$ porovnaní so študentmi bakalárskeho a magisterského/inžinierskeho štúdia, ale len na úrovni jedného ukazovatel'a diverzity, a to Tvorby inkluzívneho prostredia a kultúry. Študenti doktorandského štúdia hodnotili inkluzívne prostredie a kultúru školy negatívnejšie v porovnaní so študentmi ostatných stupňov štúdia. Z pohl'adu doktorandov sa študenti a pedagógovia nesprávajú $\mathrm{k}$ sebe dostatočne úctivo, nerešpektujú vzájomné odlišnosti, ako sú pohlavie, sociálna vrstva, etnické zázemie, a iné. Školy, podl’a zistení, neposkytujú rovnaké príležitosti všetkým študentom zapájat' sa do školských a vedeckých aktivít, ako sú napr. konferencie alebo vedecko-odborná činnost'. Školy nezapájajú do svojich aktivít žiadne komunity, prostredníctvom ktorých by bola podporená diverzita. Z pohl'adu študentov jednotlivých stupňov štúdia tiež vyplynulo, že školy uplatňujú princípy inkluzívnej filozofie, podporujú rozmanitost' študentov, školské priestory sú vybavené tak, aby umožňovali prístup aj študentom so špeciálnymi vzdelávacími potrebami, poskytujú študentom kvalitné vzdelanie, ktoré im umožňuje osobnostný rast.

Ponímanie inklúzie vo vysokoškolskom prostredí jednotlivých skúmaných vysokých škôl bolo odlišné najmä v ukazovateli Organizácia učenia, pričom významnú rolu zohrávali deklarované podporné služby, ktoré umožňujú študentom kontakt $\mathrm{s}$ ostatnými študentmi, učitel'mi, študijnými materiálmi a s akademickým prostredím. Pri porovnávaní hodnotenia inkluzivity a prijímania diverzity z hl'adiska študijného zamerania študenta sa zistilo, že študenti technických odborov podporu diverzity a mieru inkluzivity na školách hodnotia štatisticky významne pozitívnejšie ako študenti humanitných odborov.

Mnohé štúdie poskytujú dôkazy o pozitívnom vplyve diverzity študentských skupín na procesy učenia a výsledky učenia, kognitívny vývin, kritické myslenie pre všetkých študentov (Anthony, A. et al., 2004; Astin, 1993; Chang, 1999; Gurin, 1999), ako aj na vzdelávacie skúsenosti, zlepšenie zručností a afektivitu. Diverzita posilňuje medzikultúrne kompetencie, pomáha rozvíjat' vodcovské kompetencie a tímovú spoluprácu a pozitívne ovplyvňuje osobnost' tým, že rozširuje obzory a poznávanie vlastnej životnej pozície a kolektívneho miesta na svete (Gurin, Dey, Hurtado, Gurin, 2002, 2004; Smith, Schönfeld, 2000). Rozmanitost' sama o sebe však nestačí. Aby bolo možné vytvorit' inkluzívne prostredie, v ktorom sa cíti byt' prijatý každý žiak, či študent, musia byt' ovplyvňované spoločenské postoje, uskutočňované proinkluzívne stratégie a politické rozhodnutia, prispôsobené školské kurikulá, orientovaný pedagogický výskum a uplatnené pedagogické intervencie a rozvíjané efektívne študentské služby.

V nadväznosti na zahraničné zistenia sme iniciovali výskum, ktorého ciel'om bolo porovnanie sociálnych charakteristík a triednych sociálnych charakteristík základných škôl, v kontexte inkluzivity školského prostredia a hodnotenie miery inklúzie $\mathrm{z}$ pohl'adu učitel’ov príslušných základných škôl (Vargova, 2017).nVychádzali sme z predpokladu, že ak by proinkluzívna politika vytvárala funkciu inkluzívneho prostredia, sociálne charakteristiky žiakov, ako sú index vplyvu a index obl’uby, nebudú u žiakov integrovaných a intaktných významne rozdielne. $Z$ výsledkov však vyplynulo, že v indexoch vplyvu aj obl'uby v školských triedach existuje medzi žiakmi integrovanými a intaktnými štatisticky významný rozdiel. Školy síce prezentujú inklúziu ako verejnú politiku školy. Je otvorená pre všetkých a ponúka rovnaké príležitosti pri kvalitnom vzdelaní, no zistili sme že inklúzia a reflexia diverzity nemá dostatočne široký dosah na oblast' sociálnych vzt’ahov medzi žiakmi v školskej triede. Je potrebné na školách uplatňovat' všetky princípy inklúzie kam jednoznačne patrí akceptácia, tolerancia a prijatie každého žiaka. Skúmaný bol tiež vzt’ah medzi sociálnymi charakteristikami triedy, 
vyjadrenými $\mathrm{v}$ podobe triedneho indexu vplyvu a triedneho indexu obluby a proinkluzívnou politikou školy, ktorú škola deklaruje v školských dokumentoch. Očakávali sme, že triedne indexy vplyvu a obl’uby budú vyššie na školách, ktoré deklarujú v školských dokumentoch proinkluzívnu politiku, ako na školách, ktoré nemajú proinklzívnu politiku explicitne vyjadrenú v školských dokumentoch. Z výsledkov vyplynulo, že školy s proinkluzívnou politikou deklarovanou v školských dokumentoch dosahujú nižšie triedne indexy vplyvu a triedne indexy obl'uby ako školy, ktoré nemajú proinkluzívnu politiku explicitne vyjadrenú v školských dokumentoch. Príčinou môže byt' formálne stanovenie proinkluzívnej politiky v ciel'och a plánoch školy len v rovine teoretickej, čo spôsobuje, že sa proinkluzívna politika dostatočne neodráža $v$ sociálnych vzt’ahoch.

V našich podmienkach je predmetom výskumu voblasti inkluzívneho vzdelávania okrem účinnosti inkluzívnej edukácie najmä oblast' postojov jednotlivých zainteresovaných subjektov (žiakov, učitel'ov, rodičov, okolia) a efektívnost' inkluzívneho vzdelávania.

Ako ukazovatel' efektivity je riešený v mnohých výskumoch parameter spokojnosti a akademické a sociálne výsledky dosiahnuté v inkluzívnom prostredí. (Foreman, Arthur-Kelly, 2008; Freeman, Alkin, 2000; Jordan, et all, 2009; Hajkova, Strnadova, 2010, Vargova, 2017).

V prácach popredných odborníkov sa stretávame i s konfrontačnými stanoviskami na rešpektovanie, verzus nerešpektovanie individuálnych potrieb vo vyučovacom procese, kde odznievajú i názory, že zohl’adňovanie diverzity a následná diferenciácia môže viest' k vzájomnému vzd’al'ovaniu sa žiackej populácie.

Inklúzia a integrácia a ich edukačné podmienky, ako aj príprava učitel’ov na inkluzívne vzdelávanie, zdôrazňujúce rozvoj kritického a tvorivého myslenia sú predmetom aj dalších výskumov (Duchovicova, Petrova, 2017; Seidler, Zovinec, Kurincova, 2008; Babulicova, 2012), ktorých výsledky mali bezprostredný dopad na formuláciu požiadaviek vo vzt'ahu k edukačnému procesu (Pisonova, 2016, Komora Polakovicova, 2013 a i.) a didaktickú prácu učitel'ov (Fenyvesiova, 2012; Macajova Grofcikova, 2016; Slezakova Tirpakova, 2006, Kovacikova, 2009 a i.)

\section{Záver}

Vytváranie inkluzívnej školy a diferenciácia vo vzdelávaní v kontexte diverzity je výrazne ovplyvnená vnímaním, hodnotami, postojmi a poznatkami učitelov. Tieto sú v podobe intencionálneho riešenia edukačných okolností, komunikácie, kooperatívnych stratégií a osobnej angažovanosti učitel'ov modelovými situáciami a zdrojmi pre behaviorálne transmisie. Pre zúčastnené subjekty sa stávajú prostriedkom aj ohniskom sociálnej skúsenosti a utvárania vlastných postojov. V širšom ponímaní tak predstavuje diverzita a diferenciácia vo vyučovaní "investíciu do budúcej generácie“, a tým významnú výzvu pre obsahovú modifikáciu programov pregraduálnej prípravy učitel’ov ako aj programov kontinuálneho vzdelávania pedagogických zamestnancov pôsobiacich v jednotlivých stupňoch vzdelávania.

Táto práca bola podporovaná Agentúrou na podporu výskumu a vývoja na základe Zmluvy č. APVV-15-0368.

\section{Bibliographic references:}

AMINEVA, V.R. 2017. Symbolization as a way of art completion in the story by A. Eniki «Unvoiced testament» In: XLinguae, vol. 10 n. 1, pp. 12-24. ISSN 1337-8384. DOI: 10.18355/XL.2017.10.01.02

ANTHONY, A. L. et all 2004. Effects of Racial Diversity on Complex Thinking in College Students. In Psychological Science, vol. 15, n. 8, p. 507-10. 
ARAGON, S. R. - KOSE, B. W. 2007. Conceptual Framework of Cultural Capital Development: A New Perspective for the Success of Diverse College Students. In Diversity and the Postsecondary Experience. Minnesota: Education and Urban Literacy. The University of Minnesota, p.. 103-128.

ASTIN, A. W. 1993. Diversity and multiculturalism on campus: How are students affected? In Change, roč. 25, č. 2 , s. 44-49.

BABULICOVA, Z. 2012. Inkluzivna a kognitivna edukacia a jej implementacia v skole. Dizertacna praca. skolitel: doc. PaedDr. Jana Duchovicova, PhD, Nitra: PF UKF.

BAUGHN, J. R. 1999. Diversity: Finding Strength in Differences, [Online]. Available online: http: programs.eioline.netBreaking_Ranks/mod8/_expert.cfm.

BEDFORD, T. 2009. Promoting Educational Equity Through Teacher Empowerment Web-Assisted Transformative Action Research as a Counter-Heteronormative Praxis. Oulun: Faculty of Education, Oulun Ylipisto, ISBN 978-951-42-9056-5, p. 282.

BERNHARD, J. E. 2007/2008. A Differentiated Approach to Community College Language Instruction. In NECTFL Review a Journal for K-16+ Foreign Language Educators. Northeast Conference on the Teaching of Foreign Languages 2007/2008. Available online: http://nectfl.net/review61.pdf

BOOTH, T. - AINSCOW, M. 2007. Ukazovatel inkluze : rozvoj uceni a zapojeni ve skolach. Praha : Rytmus, 109 p. ISBN 80-903598-5-X.

BURJAN, V. a kol. 2017. Uciace sa Slovensko. Narodny program rozvoja vychovy a vzdelavania. Navrh na verejnu diskusiu. Bratislava: MŠVVŠSR [online]. [cit. 201710-06]. Available online: https://www.minedu.sk/data/files/6987_uciace_sa_slovensko.pdf

CAROLL, D. 1987. Paraesthetics Foucalt- Lyotard - Derrida. New York \& London: Routledge, ISBN 0-415-90291-6.

Center for Research on Education, Diversity \& Education. National Survey of Teacher Preparation Programs, Available online: http://colorado.edu/education/ BUENO/crede/intro.html.

DUCHOVICOVA A KOL. 2012. Diverzita v edukacii. Nitra : UKF, 233 s. - ISBN 978-80-558-0223-7.

DUCHOVICOVA, J. 2013a. Ponatie diverzity v školskom prostredí a aspekty pedagogickej diagnostiky v kontexte ziackej diverzity. In. Duchovicova a kol.: Diverzita skolskej populacie ako objekt pedagogickej vedy. Nitra : UKF, p. 20-95, ISBN 978-80-558-0528-3,

DUCHOVICOVA, J. - RYBANSKY, L. 2013b Varieta skolskej populacie, zastupenie jednotlivych edukacnych potrieb $\mathrm{v}$ skolskom prostredi $\mathrm{V}$ reflexii pedagogických pracovnikov. In Pedagogicke a psychologicke aspekty edukacie. Nitra : UKF, 2013. ISBN 978-80-558-0501-6. p. 134-147.

DUCHOVICOVA, J. - PETROVA,G. 2015 Diversity of school Population and its Perception in Terms of Teacher's Didactic Competence. In. International Journal of Science Commerce and Humanities. ISSN 2053-5295, Vol. 5, no. 3, p. 37-44.

DUCHOVICOVA, J. - PETROVA,G. 2017. Psychodidakticke kompetencie ucitela a moznosti ich rozvijania prostrednictvom pedagogickej praxe v konkretnych odborovych didaktikach. In Studia scientifica Fakulltatis Paedagogicae. Ruzmberok : Verbum, p. 88- 101, ISSN 1336-2232.

EQUITY. 2014. [online], [cit. 2015-01-20]. Available online: http://www.equityoz.sk/equity-a-equality

ENGLAND, J. T. 1992. Pluralism in Education: Its Meaning and Method. [Online]. Available online: http: //ed.gov/databases/ERIC/Digests/ed347494.html

FENYVESIOVÁ, L. 2012. Ucebne styly yiakov a volba vyucovacej strategie. In Civilia. Odborna revue pro didaktiku spolecenskych ved. vol. 3, n. 2, ISSN 18053963, p. 65-71. 
FEUERSTEIN, R. - RAND, Y. - HOFFMAN, M. B. - MILLER, R. 1980. Instrumental Enrichment: An intervention program for cognitive modifiability. Baltimore, MD: UPP. ISBN 0-673-24600-0.

FOREMAN, P. - ARTHUR-KELLY, M., 2008. Social Justice Principles, the Law, and Research, as Bases for Inclusion. In Australasian Journal of Special Education, vol...32, n. 1, p. 109-124.

FREEMAN, S. F. N. - ALKIN, M. C. 2000. Academic and Social Attainments of Children with Mental Retardation in General Education and Special Education Setting. In Remedial and Special Education, r. 21, č.1, s. 3-18.

GHERE, D. L. - KAMPSEN, A. - DURANCZYK, I. M. - CHRISTENSEN, L. L. 2007. Adopting and Integrating Multiculturalism: A Closing Assessment of General College. In Diversity and the Postsecondary Experience. Minnesota: Education and Urban Literacy. The University of Minnesota, s. 25 - 36

GURIN, P. Y. 1999. Expert Report of Patricia Gurin. In Michigan Journal of Race \& Law 5, s. 363-425.

GURIN, P. - DEY E.L. - HURTADO, S. - GURIN, G. 2002. Diversity and Higher Education: Theory and Impact on Educational Outcomes. In Harvard Educational Review, vol. 72, n. 3. p 330-366.

GURIN, P. - DEY, E. L. - GURIN, G. - HURTADO. S. 2004. The Educational Value of Diversity. In Defending Diversity: Affirmative Action at the University of Michigan. Ann Arbor: The University of Michigan Press,

HAJKOVA, V. - STRNADOVA, I. 2010. Inkluzivni vzdelavani. Teorie a praxe. Praha: Grada Publishing. ISBN 978-80-247-3070-7.

HALEY, M. H. - HANCOCK, CH. R. 2007/2008. Editorial Introduction - The Many Views of Diversity: Understanding Multiple Realities. In NECTFL Review a Journal for K-16+ Foreign Language Educators. Northeast Conference on the Teaching of Foreign Languages 2007/2008. Available online: http://nectfl.net/review61.pdf

HIGBEE, J. L. - LUNDELL, D. B. - DURANCZYK, I. M. (ed) 2007. Diversity and the Postsecondary Experience. Minnesota: Education and Urban Literacy. The University of Minnesota. Available online: www.cehd.umn.edu/crdeul/docs/monograph/Diversity.pdf

HIGBEE, J. L. - SIAKA, K.. - BRUCH, P. L. 2007. Assessing our commitment to multiculturalism: Student perspectives. In Journal of College Reading and Learning, vol. 37, n. 2, p. 7-25.

HURTADO, S. - MILEM, J. - CLAYTON-PEDERSEN, A. - ALLEN, W. 1999. Enacting diverse learning environments: Improving the climate for racial/ethnic diversity in higher education. Washington, D. C.: The George Washington University. CHANG, M. J. 1999. Does racial diversity matter? The educational impact of a racially diverse undergraduate population. In Journal of College Student Development, 40, p. 377-395.

CHRISTENSEN, L. L. 2007. A Case Study of Intercultural Development for PreService Language Teachers. In Diversity and the postsecondary experience. Minneapolis, MN: the University of Minnesota, Center for Research on Developmental Education and Urban Literacy. p. 69-86.

JAAP, J. 1999. Addressing Diversity: Growing Our Own Teachers in an Urban Setting, The Forum, Spring 1999.

JORDAN, A. - SCHVARZ, E. - MCGHIE-RICHMOND, D. 2009. Preparing Teachers for inclusive classrooms. In Teaching and Teacher Education, vol.. 25,p. 535-542.

KOMORA, J. - POLAKOVICOVA, R. 2013. Diverzita skolskej triedy v kontexte inkluzivneho vzdelavania ziackej populacie. 1. vyd. Nitra : UKF, 136 s. ISBN 978-80558-0379-1.

XLinguae, Volume 11 Issue 1XL, January 2018, ISSN 1337-8384, eISSN 2453-711X 
KOVACIKOVA, E. 2009. English for Specific Purposes in Agriculture . Nitra : SPU, 2009. - 110 p. ISBN 978-80-552-0276-1.

LINEVA, E.A. - SAVELYEVA, E.B. - YUSUPOVA, T.G. 2017. Andre Gide's life

philosophy: "Russian trace" In: XLinguae, vol. 10 n. 3, pp. 184-201. ISSN 1337-

8384. DOI: 10.18355/XL.2017.10.03.15

MACAJOVA, M. - GROFCIKOVA, S. 2016. Analyza pojmoslovia v oblasti fonematického uvedomovania In: LLCE 2016 : sucasne vyzvy vo vyucovani jazykov: ako d'alej? Nitra : SlovakEdu, p. 265-281. ISBN 978-80-89864-00-3,

MURRY, V. M. 2006. An Ecological Framework for Engaging Communities in Diversity and Learning. In HILL, J. R. - FECHO, B. - OLIVER, J. P. - GUY, T.C. (Eds.) The Intersection of Diversity and Learning: Capturing a Conversation. A monograph based on a two-day conference at The University of Georgia. Available online: http://janette.myweb.uga.edu/diversity/Community_Murry

NIETO S. 2006. Diversity, Access, Equity, and Learning: Conditions to Promote Learning and Principles for Practice. In HILL, J.R. - FECHO, B. - OLIVER, J.P. GUY, T.C. (Eds.) The Intersection of Diversity and Learning: Capturing a Conversation. A monograph based on a two-day conference at The University of Georgia. Available online: http://janette.myweb.uga.edu/diversity/K-12_Nieto

PINTES, G. 2013. Teoreticko-koncepeny kontext diverzity $\mathrm{v}$ edukacii . In: Duchovicova, J. a kol.: Diverzita skolskej populacie ako objekt pedagogickej vedy. 1. vyd. - Nitra : UKF, 2013. - ISBN 978-80-558-0528-3,

PISONOVA, M. 2016. Philosophical Explication of requirements on the Process of Education - Novelty or Relic? XLinguel, vol. 9. Issue 1, p. 83 - 90, ISSN 1337 8384.

RIFKIN, B. 2007/2008. Attending to Learner Diversity in the Lesson Plan: Planning for Intensity of Engagement. In NECTFL Review a Journal for K-16+ Foreign Language Educators. Northeast Conference on the Teaching of Foreign Languages 2007/2008. Available online: http://nectfl.net/review61.pdf

SEIDLER, P. - ZOVINEC, E. - KURINCOVA, V. 2008. Edukacia a inkluzia ziakov so specialnymi potrebami. Nitra : CCV PF UKF, 2008. 80 s. ISBN 978-80-8094-2922 .

SLEZAKOVA, T. - TIRPAKOVA, A. 2006. Adaptacia dietata na skolu : sucasne pohlady na pedagogicku teoriu a vyskum. Nitra : UKF, 181 p. ISBN 80-8050-968-9.

SMITH, D. G. - SCHONFELD, N. B. 2000. The Benefits of Diversity: What the Research Tells Us. In About Campus 5, n. 5 p. 16-23.

STANLEY, CH. A. 2006. A Critical Look at the Diversity of the Professoriate. In HILL, J. R. - FECHO, B. - OLIVER, J. P. - GUY, T.C. (Eds.) The Intersection of Diversity and Learning: Capturing a Conversation. A monograph based on a two-day conference at The University of Georgia. Available online: http://janette.myweb.uga.edu/diversity/Faculty_Stanley

TEELE, S. 2007/2008. Teaching Literacy to Culturally and Linguistically Diverse Learners through Multiple Intelligences. In NECTFL Review a Journal for K-16+ Foreign Language Educators. Northeast Conference on the Teaching of Foreign Languages 2007/2008. Available online: http://nectfl.net/review61.pdf

THARP, R. G. 1994. Research knowledge and policy issues in cultural diversity and education. In B. McLEOD (Ed.), Language and learning: Educating linguistically diverse students. Albany. NY: State University of New York Press.

VANCOVA, A. 2016. The current research view on the issue of special educational diagnostics, special educational counseling and early intervention for children with disabilities in Slovakia. Turkish Online Journal of Educational Technology. Special Issue December, pp. 1401-1412. ISSN 1303-6521.

VARGOVA, M. 2015. Diverzita studentskej populacie ako vychodisko inovacii v terciarnom vzdelavani. [diplomová práca] - školitel': doc. PaedDr. Jana Duchovicova, PhD., Nitra: KPG PF UKF, 2015. 86 p. 
VARGOVA, D. 2017. Diverzita edukacneho prostredia a charakteristiky socialnych vztahov ziakov v skolskej triede. [diplomova praca] - skolitel: doc. PaedDr. Jana Duchovicova, PhD., Nitra: KPG PF UKF, p. 80.

VERMA, B. 2006. Creating a Culture for Inquiring into the Value of Diversity in Learning. In HILL, J.R. - FECHO, B. - OLIVER, J.P. - GUY, T.C. (Eds.) The Intersection of Diversity and Learning: Capturing a Conversation. A monograph based on a two-day conference at The University of Georgia. Available online: http://janette.myweb.uga.edu/diversity/InquiryDiversity_Verma

Words: 6832

Characters: 52625 (29,24 standard pages)

doc. PaedDr. Jana Duchovičová, PhD.

Univerzita Konštantína Filozofa v Nitre

Pedagogická fakulta, Katedra pedagogiky

Dražovská cesta 4, 94974 Nitra

Slovakia

jduchovicova@ukf.sk 